\title{
Trophic control of bacterial growth in microcosms containing a natural community from northwest Mediterranean surface waters
}

\author{
T. Frede Thingstad ${ }^{1, *}$, Maite Pérez ${ }^{2}$, Silvia Pelegri $^{2}$, John Dolan $^{2}$, \\ Fereidoun Rassoulzadegan ${ }^{2}$
}

\author{
${ }^{1}$ Dept of Microbiology, University of Bergen, Jahnebakken 5, N-5020 Bergen, Norway \\ ${ }^{2}$ Station Zoologique, CNRS ESA 7076, Marine Microbial Ecology Group, BP 28, F-06230 Villefranche-sur-Mer, France
}

\begin{abstract}
A simple steady-state model based on P-limited bacterial growth rate and predator controlled bacterial biomass predicts bacterial production $(B P)$ to be proportional to the square of ciliate biomass $(C)$. Changes in ciliate biomass will then drive changes in bacterial production and carbon demand. This model was compared to experimental microcosms where natural mixed microbial communities from Villefranche Bay (northwest Mediterranean) were given daily additions of phosphate and glucose in a factorial design. In accordance with the proposed model, we found no effect of glucose additions on the incorporation of ${ }^{14} \mathrm{C}$-leucine, except when combined with phosphate. Phosphate enrichment had a stimulatory effect on bacterial production, even when no glucose was added, but after an initial phase of ca $2 \mathrm{~d}$, leucine incorporation increased more in carboys receiving glucose and phosphate in combination than in carboys enriched with phosphate alone. After 3 to $4 \mathrm{~d}$, leucine incorporation culminated. These observations are consistent with a scenario where, initially, bacterial growth rate was P-limited. Stimulation of bacterial carbon demand resulting from transfer of added phosphorus into ciliate biomass was, however, apparently larger than the increase in the system's production of labile organic $\mathrm{C}$. The explanation suggested for the observed culmination in bacterial production is thus a switch from P- to C-limited bacterial growth rate. In such a scenario, glucose addition allows a larger increase in bacterial consumption before the pool of labile DOC is depleted. DOC accumulation was found only in carboys to which glucose was added without phosphate.
\end{abstract}

KEY WORDS: Bacterial carbon demand - Predation - Algal-bacterial competition - Microbial food webs

\section{INTRODUCTION}

Although by now there is a vast literature on the ecology of microorganisms in the ocean's pelagic photic zone, there are still problems in assembling this knowledge into an integrated description that can serve the strongly needed function of a tool for analysing the behavior of the microbial food web in experimental situations and in observed natural systems. As one aspect of this imperfection in the state of the art, one might be tempted to claim that our understanding of the mechanisms regulating bacterial pro-

\footnotetext{
•E-mail: frede.thingstad@im.uib.no
}

duction in this ecosystem is not nearly as advanced as one might have hoped for, nearly 2 decades after the introduction of methods allowing its estimation in natural populations (Hagström et al. 1979, Fuhrman \& Azam 1980, 1982). Since bacterial production is closely linked to the process of remineralizing dead organic matter, which would otherwise be subject to potential transport to the deep ocean, a correct understanding of how bacterial production is controlled is not only an interesting subject per se, but also one crucial to the understanding of the ocean's biogeochemical cycle of carbon.

Bacterial production is the product of specific growth rate and biomass, and models of bacterial production 
thus have to consider the mechanisms controlling both of these. Most of the thinking on the control of the growth rate of heterotrophic bacteria seems to have been centered around the idea that bacterial growth rate is $\mathrm{C}$-limited, in which case the reason for changes observed in bacterial growth rate would have to be sought in changes in the rate at which degradable organic substances are made available to the bacteria. Observations suggest, however, that mineral nutrients may limit the growth rate of heterotrophic bacteria in the pelagic photic zone, at least in $\mathrm{P}$-deficient regions (Thingstad et al. 1993, 1998, Zweifel et al. 1993, Pomeroy et al. 1995, Cotner et al. 1997, Zohary \& Robarts 1998). If this is true, phytoplankton-bacterial competition for mineral nutrients will influence production as well as consumption of organic $C$ in the surface layer. In models of the type used here, predation is an important factor in regulating biomass of the different competitors, and the outcome of nutrient competition is thus not only dependent upon the relative abilities of the competitors to sequester the limiting substrate, but also highly dependent upon the difference in predation pressure on the competing populations of heterotrophic bacteria and phytoplankton. Adding the idea that mineral nutrient limitation of phytoplankton biomass production may enhance the excretion of dissolved C-rich organic compounds (Williams 1990), we rapidly reach a level of complexity in interactions where deduction of even qualitative aspects of system behavior is no longer a trivial exercise. Although such deduction may not be too difficult for some situations characterized by uncoupled growth of the different populations, such as the early phase of a spring bloom, understanding the mechanisms regulating system behavior of climax communities close to steady state is far from trivial. Close to steady state, the populations of predators and competitors are tightly coupled, cause and effect relationships become circular, and 'everything depends on everything'. If the proper equations can be formulated, however, the steady state is in principle amenable to the relatively powerful technique of analytical solution of a set of algebraic equations, often providing a better comprehension of how things are related than the alternative technique of numerical solution of sets of coupled differential equations.

In many experimental and observational datasets, however, the feature of prime interest is the variation in population abundance and substrate concentrations over time. This may, at first sight, seem to severely restrict the applicability of steady state solutions. What one then perhaps may have overlooked is that all dynamic systems have a hierarchy of dynamic levels, although for practical purposes, the fast dynamics of lower levels may often be ignored. As a relevant example, most models of microbial ecosystem dynamics will implicitly contain the assumption that the response of membrane transport systems to changes in substrate concentration is very fast. For most purposes, the relationship between substrate concentration and uptake rate can then be satisfactorily described using the steady-state solution of the transport system, i.e. usually a Michaelis-Menten type relationship (see e.g. p. 63-64 in Dixon \& Webb 1964). At the level of population dynamics, there is also a hierarchy in response times with small heterotrophic organisms being able to grow at minimum generation times less than $1 \mathrm{~h}$, while large predators feeding on the micro-organisms, such as copepods, may have characteristic generation times typically of 2 to $4 \mathrm{wk}$ (Landry 1983). This introduces the tempting theoretical possibility that a better understanding of the mechanisms controlling the microbial food web can perhaps be gained from an approximate description where a sub-system comprising the smaller organisms of the food web is assumed to be in steady state, although this steady state may change at a rate determined by the relatively slower changes in populations of larger predators. If applicable, this approach would combine the analytical power of steady state solutions with the dynamic properties and generality of numerically solved differential equations.

The present study explores this approach by building upon a previously published steady state model for the system of heterotrophic bacteria, their protozoan predators, and their phytoplankton competitors for mineral nutrients (Thingstad et al. 1997). This has here been expanded to include 2 size classes of phytoplankton and 2 size classes of heterotrophic flagellates (Fig. 1). The changes in steady state of this sub-system are driven by autochthonous input of phosphate and degradable organic $\mathrm{C}$, and by predation from ciliates. The results are compared to an experiment where phosphate and glucose were added in a factorial design to $20 \mathrm{l}$ microcosms containing surface water with its indigenous microbial population, collected from Villefranche Bay (northwest Mediterranean).

\section{MODEL}

In the present context we are interested in the 2 possibilities that either (1) bacterial growth rate is C-limited in the sense that consumption of labile dissolved organic carbon (L-DOC) consumption is equal to the sum of input of degradable DOC from autochthonous and allochthonous sources, or (2) growth rate is controlled by the concentration of a limiting mineral nutrient (Class 1 and Class 3 models, respectively, in the scheme of Thingstad \& Lignell 1997). In the first case, 


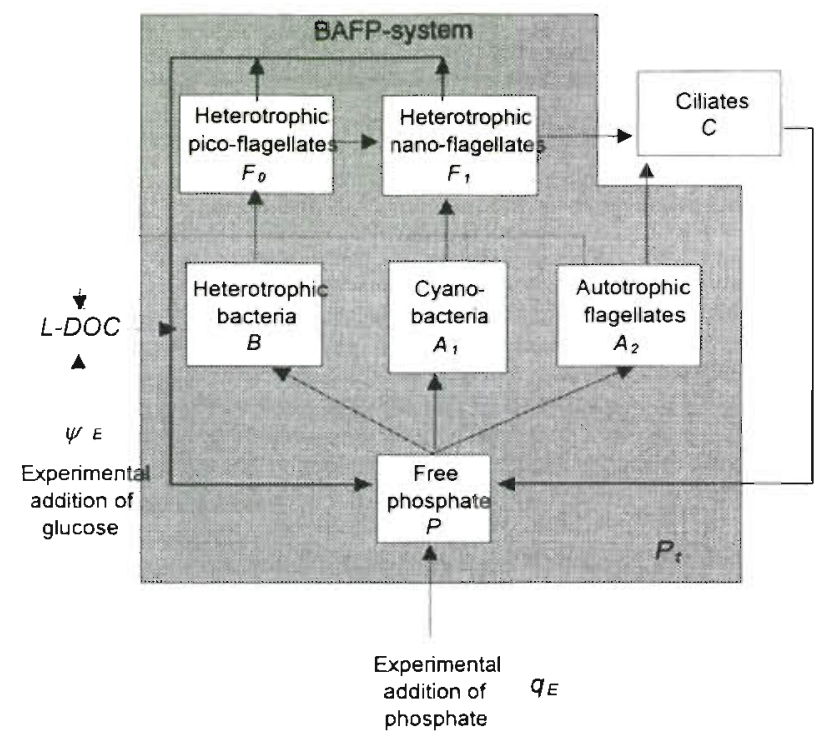

Fig. 1. Flow scheme for model used. Flows of phosphorus (solid arrows) and of labile dissolved organic carbon (L-DOC) (dotted arrows). The part of the phosphorus cycle inside the shaded area (the BAFP system) is assumed to be in internal equilibrium. There are 2 types of these equilibria, depending upon whether growth rate of the heterotrophic bacteria is $\mathrm{P}$ or C-limited. Also, these equilibria depend on the total amount of nutrients $\left(P_{\mathrm{t}}\right)$ in the BAFP system, and the predation pressure from ciliates. The equilibrium state of the BAFP system thus changes over time as phosphorus is added as phosphate or transferred via predation to ciliates. Recycling pathways inside the BAFP system are omitted for clarity

bacterial growth rate will be a function of the processes supplying L-DOC, in the second case, bacterial growth rate is a result of the outcome of bacterial competition with phytoplankton for the limiting mineral nutrient. The heterotrophic bacteria $(B)$ are in our model linked to phytoplankton (Fig. 1) in a competitive-commensal relationship (Bratbak \& Thingstad 1985) where cyanobacteria $\left(A_{1}\right)$ and autotrophic flagellates $\left(A_{2}\right)$ excrete L-DOC functioning as the carbon substrate for bacterial growth, while at the same time the heterotrophic bacteria have to compete with these phytoplankters for free phosphate $(P)$. Focusing on the mechanisms controlling consumption rather than on those leading to production of L-DOC, production is here for simplicity assumed to occur only from phytoplankton and to be proportional to phytoplankton biomass (Bjørnsen 1988). The model structure of the predator food web is deliberately kept simple, with predation on heterotrophic bacteria assumed to be by heterotrophic picoflagellates $\left(F_{0}\right)$ only. Heterotrophic nanoflagellates $\left(F_{1}\right)$ are assumed to prey on cyanobacteria and on heterotrophic picoflagellates. All variables except L-DOC are in phosphate units. In analogy with the procedure suggested by Thingstad et al. (1999), the
$P$ cycle of the sub-system consisting of $B, A_{1}, A_{2}, F_{0}, F_{1}$, and $P$, subsequently called the BAFP system, is assumed to be close to internal steady state at the time of measurement. As is shown in Appendices $2 \& 3$, the steady state is dependent upon the total amount of phosphorus $\left(P_{i}\right)$ shared among the components of the BAFP system and on the biomass $(C)$ of a ciliate assemblage assumed to prey on $A_{2}$ and on $F_{1}$. The steady state is thus dependent upon whether bacterial growth rate is L-DOC or P-limited, and shifts as $P_{\mathrm{t}}$ increases due to allochthonous addition of orthophosphate or decreases due to transfer of phosphorus from $P_{\mathrm{t}}$ to $C$ by ciliate predation on $A_{2}$ or $F_{1}$.

This model is built on the one suggested by Thingstad et al. (1999), modified with mechanisms allowing the system to switch between P- and C-limited bacterial growth rate. Here we have also added cyanobacteria and an extra group of heterotrophic flagellates preying on these $\left(F_{1}\right)$. This was done because the observations indicated different dynamics for the 2 groups of phytoplankton. As long as the model is restricted to the simple 'ladder-like' trophic structure of Fig. 1, with no predator feeding on more than 1 of the competing osmotrophs, the group of largest phytoplankton (here $A_{2}$ ) will increase with $P_{\mathrm{t}}$ and decrease with $C$ (Eq. 12). $A_{1}$ will increase proportionally to $C$ (Eq. 11), as will the other functional groups within the steadȳ state system.

There is 1 steady state condition for each component of the BAFP system, leading to 6 algebraic equations with 6 unknowns (Appendix 1). These can be solved explicitly in terms of $C$ and nutrient content $\left(P_{t}\right)$ of the BAFP system. There will be 2 different solutions, one for P-limited (Appendix 2), and one for C-limited (Appendix 3) bacterial growth rate. The dynamics of $C$, $P_{1}$ and L-DOC are governed by differential equations (Appendix 4). The source term for $P_{\mathrm{t}}$ is the phosphate addition to the carboys, and the sink term is the transfer from the BAFP system into ciliates. The source term for L-DOC is excretion from phytoplankton and glucose addition, and the sink term is bacterial carbon demand. With numerical values set for the initial conditions of $C$ and $P_{t}$, and for the parameters, the set of equations in Appendix 1 can be solved. For this purpose, we used a simple 1-order Euler algorithm with $2 \mathrm{~h}$ time step for the differential equations, implemented in an Excel $^{(0}$ spreadsheet. Numerical values used for model parameters, for initial values, and for conversion factors used to convert model parameters into units comparable to observed entities, are given in Table 1.

The second-power dependence of bacterial production $(B P)$ on the amount of phosphorus transferred to ciliates is shown by deriving the explicit solution for $B P$ in terms of phosphorus in $C$ (Eq. 13). 


\section{MATERIALS AND METHODS}

Water collection and experimental design. Eight microcosms were established by filling 20 I translucent polyethylene carboys, thoroughly rinsed with seawater, with surface water collected from 'point B' at the entrance of Villefranche Bay, northwest Mediterranean in the late summer (September 18, 1997). To minimize potential variability between carboys they were sequentially filled with ca $5 \mathrm{l}$ aliquots up to $20 \mathrm{l}$. The carboys were incubated under natural light and temperature conditions suspended in an open tank with running seawater on the pier of the Station Zoologique, Villefranche-sur-Mer. Water temperature throughout the experiment remained at $26 \pm 1^{\circ} \mathrm{C}$.

From September 19, samples from the carboys were collected daily at 10:00 h, followed immediately by addition of the daily dose of nutrients. These were added from sterile aqueous solutions to final concentrations given in Table 2. All microcosms received nitrate to avoid any $N$ limitation throughout the experiment. For phosphate and glucose, the micro-

Table 1. Symbols used to describe mineral nutrient flux through the food web

\begin{tabular}{|c|c|c|c|c|}
\hline Symbol & Meaning & & Vaiue used & Unit \\
\hline \multicolumn{5}{|c|}{ STATE VARIABLES } \\
\hline$p$ & Free phosphate & & & $n m o l ~ P d^{-3}$ \\
\hline$B$ & Heterotrophic bacteria & & & $\mathrm{nmol} P \mathrm{dm}^{-3}$ \\
\hline$A_{1}$ & Cyanobacteria & & & $\mathrm{nmol} P \mathrm{dm}^{-3}$ \\
\hline$A_{2}$ & Autotrophic flagellates & & & $\mathrm{nmol} P \mathrm{dm}^{-3}$ \\
\hline$F_{0}$ & Heterotrophic picoflagellates & & & nmol $P d^{-3}$ \\
\hline$F_{1}$ & Heterotrophic nanoflagellates & & & $\mathrm{nmol} P \mathrm{dm}^{-3}$ \\
\hline$P_{\mathrm{t}}$ & Total nutrient in BAFP system & Initial: & 90 & $\mathrm{nmol} P \mathrm{dm}^{-3}$ \\
\hline C & Ciliate biomass & Initial: & 12 & $\mathrm{nmol} P \mathrm{dm}^{-3}$ \\
\hline L-DOC & Labile dissolved organic carbon & Initial: & 100 & nmol C dm ${ }^{-3}$ \\
\hline R-DOC & Recalcitrant dissolved organic carbon & Initial: & 91000 & $\mathrm{nmol} \mathrm{C} \mathrm{dm^{-3 }}$ \\
\hline \multicolumn{5}{|c|}{ PHYSIOLOGICAL PARAMETERS } \\
\hline \multicolumn{5}{|c|}{ Affinity constants and clearance rates } \\
\hline$\alpha_{B}$ & Bacterial affinity for free mineral nutrients & & 0.1 & $\operatorname{lnmol} \mathrm{P}^{-1} \mathrm{~h}^{-1}$ \\
\hline$\alpha_{A_{1}}$ & Cyanobacterial affinity for free mineral nutrients & & 0.045 & l nmol $\mathrm{P}^{-1} \mathrm{~h}^{-1}$ \\
\hline$\alpha_{A_{2}}$ & Autotrophic flagellates, affinity for free mineral nutrients & & 0.036 & lnmol $P^{-1} h^{-1}$ \\
\hline$\alpha_{F_{0}}$ & Heterotrophic picoflagellates, clearance rate for bacteria & & 0.005 & lnmol $P^{-1} h^{-1}$ \\
\hline$\alpha_{F_{l}}$ & $\begin{array}{l}\text { Heterotrophic nanoflagellates, clearance rate for heterotrophic } \\
\text { picoflagellates and cyanobacteria }\end{array}$ & & 0.004 & $1 \mathrm{nmol} \mathrm{P} \mathrm{P}^{-1} \mathrm{~h}^{-1}$ \\
\hline$\alpha_{C}$ & Ciliates, clearance rate for autotrophic flagellates & & 0.0008 & $\operatorname{lnmol} P^{-1} \mathrm{~h}^{-1}$ \\
\hline$\beta_{C}$ & Ciliate selectivity for heterotrophic nanoflagellates & & 1 & Dimensionless \\
\hline \multicolumn{5}{|l|}{ Yields } \\
\hline$Y_{F_{0}}$ & Fraction of $\mathrm{P}$ in prey incorporated into heterotrophic picoflagellates & & 0.4 & Dimensionless \\
\hline$Y_{F_{1}}^{0}$ & Fraction of $\mathrm{P}$ in prey incorporated into heterotrophic nanoflagellates & & 0.4 & Dimensionless \\
\hline$Y_{C}$ & Fraction of $\mathrm{P}$ in prey incorporated into ciliates & & 0.4 & Dimensionless \\
\hline$Y_{B C}$ & Fraction of organic $\mathrm{C}$ incorporated into bacterial biomass & & 0.3 & Dimensionless \\
\hline \multicolumn{5}{|l|}{ Other } \\
\hline$\delta_{c}$ & Ciliate intrinsic death rate & & $2.5 \%$ & $h^{-1}$ \\
\hline$k$ & Fraction of phytoplankton $C$ excreted & & $1 \%$ & $h^{1}$ \\
\hline$r_{p}$ & Protist C:P ratio & & 1.06 & mol C:mol P \\
\hline$r_{B}$ & Bacterial C:P ratio & & 50 & mol C:mol P \\
\hline \multicolumn{5}{|c|}{ CONVERSION FACTORS } \\
\hline & Bacterial P cell ${ }^{-1}$ & & $3.3 \times 10^{-8}$ & nmol $P$ cell $^{-1}$ \\
\hline & Cyanobacterial P cell ${ }^{-1}$ & & $7.9 \times 10^{-7}$ & nmol $P$ cell ${ }^{-1}$ \\
\hline & Flagellate $\mathrm{P}$ cell ${ }^{-1}$ & & $1.6 \times 10^{j}$ & nmol P cell ${ }^{-1}$ \\
\hline & Ciliate P cell ${ }^{-1}$ & & $1.6 \times 10^{-3}$ & nmol P cell -1 \\
\hline \multicolumn{5}{|c|}{ INPUT RATES } \\
\hline$q_{E}$ & Allochthonous input of orthophosphate & & 0 or 50 & nmol P dm $\mathrm{dm}^{-3} \mathrm{~d}^{-1}$ \\
\hline$\psi_{E}$ & Allochthonous input of L-DOC (glucose) & & 0 or 10000 & nmol C dm ${ }^{-3} \mathrm{~d}^{-1}$ \\
\hline$\psi$ & Total supply rate (allochthonous + autochthonous) of L-DOC & & & nmol $C \mathrm{dm}^{-3} \mathrm{~d}^{-1}$ \\
\hline
\end{tabular}


Table 2. Daily nutrient additions (in nmol $\mathrm{dm}^{-3}$ ) to microcosms

\begin{tabular}{|lrcc|}
\hline \multirow{2}{*}{ Microcosm treatment } & \multicolumn{3}{c|}{ Nutrient added } \\
& $\mathrm{PO}_{4}-\mathrm{P}$ & Glucose-C & $\mathrm{NO}_{3}-\mathrm{N}$ \\
\hline Control $(\mathrm{K})$ & 0 & 0 & 2000 \\
Phosphate (P) & 50 & 0 & 2000 \\
Glucose (G) & 0 & 10000 & 2000 \\
Phosphate and glucose (PG) & 50 & 10000 & 2000 \\
\hline
\end{tabular}

cosms were treated in pairs, allowing 4 different treatments, subsequently denoted with the following codes: ' $\mathrm{K}$ ' for controls receiving nitrate only, ' $\mathrm{P}$ ' for those receiving phosphate and nitrate, ' $G$ ' receiving glucose and nitrate, and 'PG' receiving glucose, phosphate, and nitrate. To keep a constant added concentration, the amount added was adjusted each day according to water volume remaining in the carboys after sampling.

Leucine incorporation. Leucine incorporation was determined according to Smith \& Azam (1992), except that ${ }^{14} \mathrm{C}$-labelled $\left(112 \mathrm{GBq} \mathrm{mmol}^{-1}\right)$ was used instead of ${ }^{3} \mathrm{H}$-labelled leucine. Leucine was added to a final con-

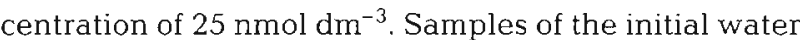
to which twice the concentration of labelled leucine had been added showed less than $10 \%$ increase in incorporation

Nutrients and chlorophyll. Concentrations of $\mathrm{NO}_{3}{ }^{-}$ and $\mathrm{PO}_{4}{ }^{3-}$ were determined on Days $0,3,4,5$, and 6 prior to nutrient additions, except on Day 0 when samples were taken both before and after additions. Samples were processed using an autoanalyser system (EV2-Alliance Instruments) according to Tréguer \& Le Corre (1975). Detection limits were $0.05 \mu \mathrm{M} \mathrm{NO}_{3}^{-}$and $0.02 \mu \mathrm{M} \mathrm{PO}_{4}{ }^{-3}$. Samples for chlorophyll estimations were taken on Days 4, 5, and 6. Samples (500 ml) were retained on Whatman $\mathrm{GF} / \mathrm{F}$ filters, extracted overnight in $90 \%$ acetone. Concentrations were determined fluorometrically.

Enumerations of microbial populations. Samples for counts of flagellates, cyanobacteria and heterotrophic bacteria were fixed with buffered formalin ( $2 \%$ final conc.) and stored refrigerated and in darkness until slides were prepared, a maximum of $1 \mathrm{wk}$ after sample collection. For counts of heterotrophic bacteria and cyanobacteria, aliquots of $10 \mathrm{ml}$ were DAPI-stained (Porter \& Feig 1980), filtered on $0.2 \mu \mathrm{m}$ pore size black polycarbonate filters and mounted onto slides. For flagellate enumeration, $10 \mathrm{ml}$ aliquots were filtered onto $0.8 \mu \mathrm{m}$ pore size filters. Slides were stored frozen at $-20^{\circ} \mathrm{C}$ until examination using a Zeiss Axiophot epifluorescence microscope. Samples for counts of ciliates were fixed with acid Lugol ( $2 \%$ final conc.). Aliquots $(50 \mathrm{ml})$ were sedimented and examined using a Zeiss
Axiophot inverted microscope. The entire surface of the settling chamber was scanned at $200 \times$ and ciliates classified into various size-shape categories. Ciliate count data were converted into carbon biomass by calculating biovolumes for size-shape categories and using a conversion factor of $0.2 \mathrm{pg} \mathrm{C} \mu \mathrm{m}^{-3}$ biovolume established for marine ciliates fixed with $2 \%$ Lugol (Putt \& Stoecker 1989).

Dissolved organic carbon. Supor filters $(0.2 \mu \mathrm{m}$ pore size polyethersulphone) were used to determine DOC concentrations. Filters were acid-washed $(10 \% \mathrm{HCl})$ and once placed onto the filtering unit $\left(500^{\circ} \mathrm{C} 4 \mathrm{~h}\right.$ ignited Millipore glassware), the filters were washed again with $20 \mathrm{ml}$ Milli-Q water and $10 \mathrm{ml}$ sample. Filtrates were collected in $20 \mathrm{ml}$ ignited Pyrex glass tubes. Samples to check Supor filter blanks were also taken. Filtered samples were acidified to $\mathrm{pH} \approx 2$ with $2 \mathrm{~N} \mathrm{HCl}$ and stored at $5^{\circ} \mathrm{C}$ pending analysis by hightemperature catalytic oxidation (HTCO) (Sugimura \& Suzuki 1988). Samples were sparged with an artificial gas mixture (AGA, France) (containing $\leq 0.1 \mathrm{ppm} \mathrm{CO}$, $\mathrm{CO}_{2}$ or hydrocarbons) in order to eliminate inorganic carbon, and measured on a Shimadzu TOC-5000 instrument equipped with a high sensitivity catalyst. Organic carbon concentrations were calculated with the instrument software and a 4 -point standard calibration curve made with potassium biphthalate. Standard deviation of duplicate injections was always $<2 \%$

\section{EXPERIMENTAL RESULTS AND COMPARISON WITH MODEL PREDICTIONS}

Throughout the experiment nutrient measurements showed detectable nitrate in all microcosms with phosphorus additions ( $P$ and $P G$ microcosms) ( $>0.4 \mu \mathrm{mol}$ $\mathrm{dm}^{-3}$ ) and accumulation in microcosms without phosphorus additions ( $\mathrm{K}$ and $\mathrm{G}$ microcosms) (final $\mathrm{NO}_{3}{ }^{-}=$ $9 \mu \mathrm{mol} \mathrm{dm}^{-3}$ ). Orthophosphate was below detection limit at all times in all microcosms (data not shown). The goal of avoiding nitrogen limitation at any stage was therefore probably achieved.

Bacterial leucine incorporation was not affected by the addition of glucose alone ( $G$ compared to $\mathrm{K}$ microcosms) while it was stimulated by the addition of phosphate (P compared to $\mathrm{K}$ microcosms). The stimulatory effect was further enhanced by combining the phosphate addition with glucose ( $\mathrm{PG}$ compared to P microcosms) (see Fig. 2B). After a period of 3 to $4 \mathrm{~d}$, leucine incorporation culminated in both $\mathrm{P}$ and $\mathrm{PG}$ microcosms. In the model where $B P$ increases as the square of $C$ until the pool of L-DOC is consumed, the same relative levels of BP are achieved (Fig. 2A) as observed experimentally (Fig. 2B), but the model gives a discon- 

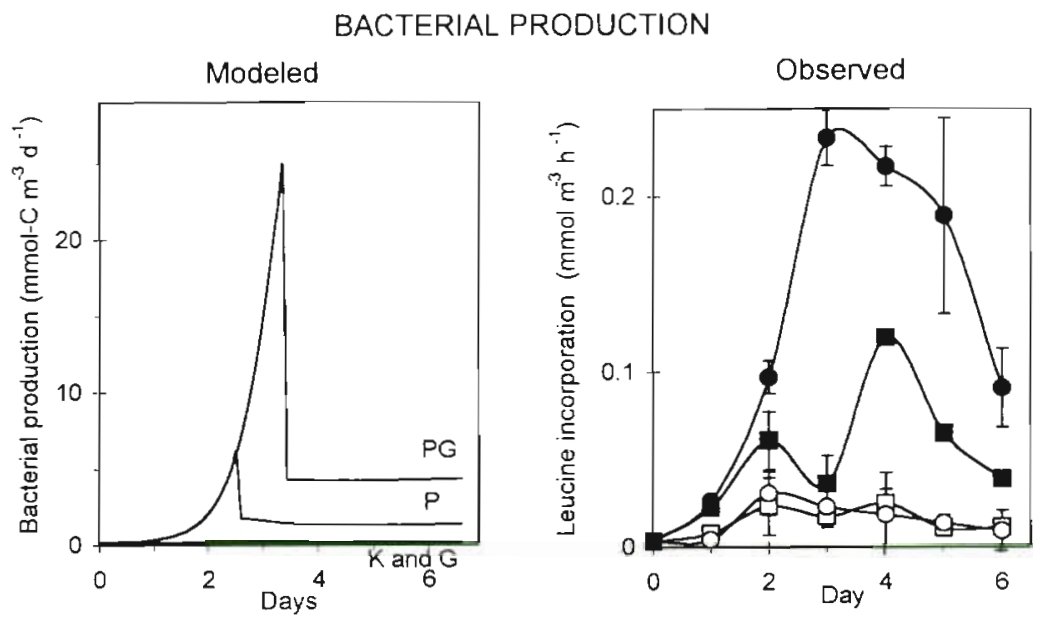

BACTERIAL PRODUCTION verSUS CILIATE BIOMASS
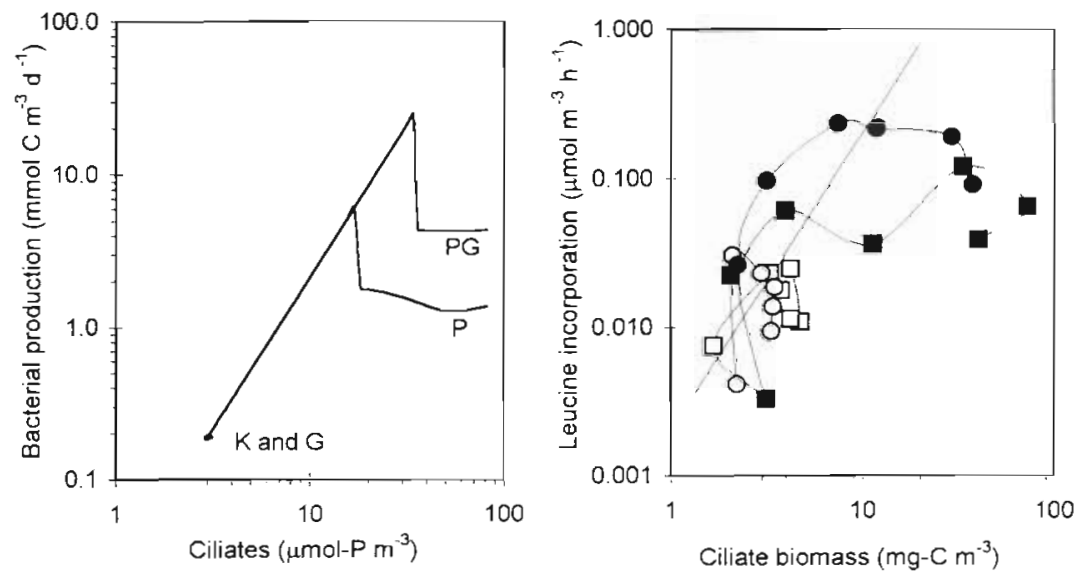

Fig. 2. (A, C) Modeled and (B, D) observed values for leucine incorporation plotted versus time $(A, B)$ and versus ciliate biomass in $\log$-log plots (C, D). Points indicate mean and error bars indicate range between 2 parallel carboys.

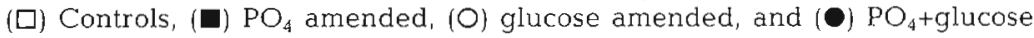
amended carboys

state assumption. If the BAFP system does not reach perfect internal steady state between nutrient addition and measurement, the P-limited bacteria would be expected to react faster than the ciliates to $\mathrm{PO}_{4}$ addition, thus shifting the points upwards in our plot of $B P$ versus $C$.

The model predicts a small initial peak in L-DOC in the microcosms receiving phosphate ( $\mathrm{P}$ and PG compared to $\mathrm{K}$ microcosms), while, in the microcosms receiving glucose only, L-DOC should accumulate essentially at the rate of addition of glucose (G microcosms). Again, this pattern is qualitatively in accordance with our observations (Fig. 3).

In the model, the main pattern of succession is one where the added phosphate initially leads to a build-up of the population of autotrophic flagellates. Due to increased food supply, this leads to a response in ciliate number with decreasing autotrophic flagellate abundance, and increasing abundance in the other populations as a result. The variation predicted for autotrophic flagellates, heterotrophic bacteria, and ciliates as a response to added phosphate ( $\mathrm{P}$ and $\mathrm{PG}$ compared to $\mathrm{K}$ and $\mathrm{G}$ microcosms) corresponds roughly to what was observed (Fig. 4), although, in the model, the peak in abundance of autotrophic flagellates is tinous drop in BP at the moment of L-DOC depletion, not seen in the experimental data. To compare experimental results to the model's predicted relationship between $B P$ and $C$, leucine incorporation is plotted versus $C$ in a $\log$-log plot. For the period of P-limited bacterial growth rate, the model predicts a straight line with slope $2(B P \propto$ $C^{2}$ ) (Fig. 2C). For the experimental data (Fig. 2D), the line $y=0.002 \mathrm{nM}$ leucine $\mathrm{h}^{-1}$

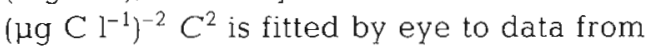
the period before culmination of leucine incorporation. Compared to this line, there is an initial phase in the experimental data where leucine incorporation in $\mathrm{P}$ and $\mathrm{PG}$ microcosms increases faster than predicted by the model, a difference which probably can be explained as a result of our steady-

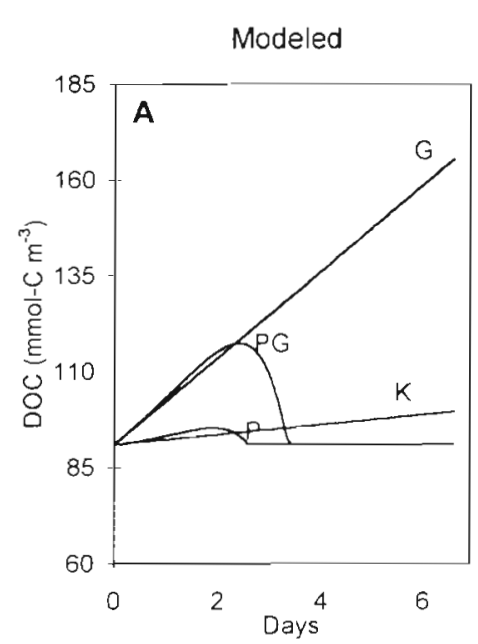

DOC

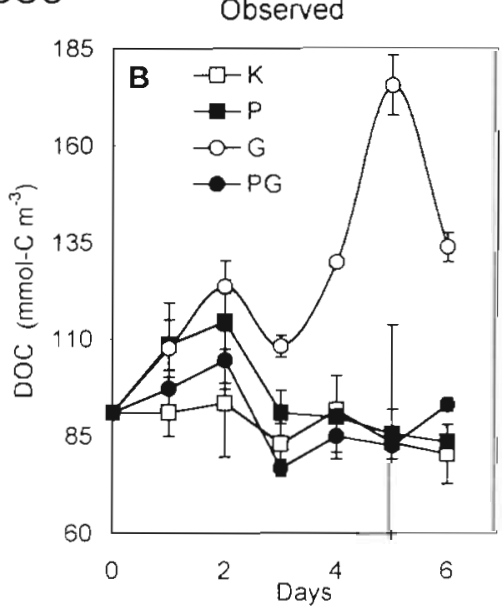

Fig. 3. (A) Model and (B) experimental results for DOC. Error bars denote the range between 2 parallel carboys 
BACTERIA

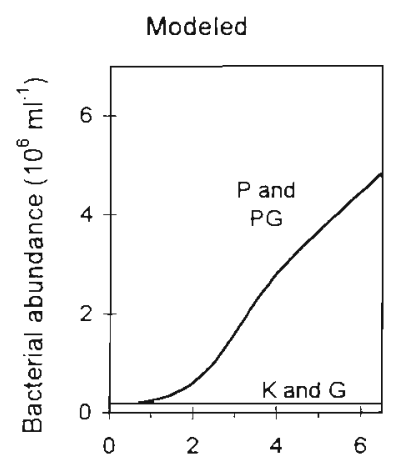

Observed

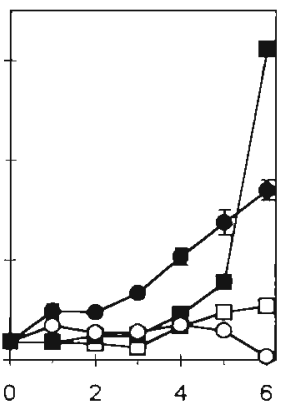

HETEROTROPHIC FLAGELLATES
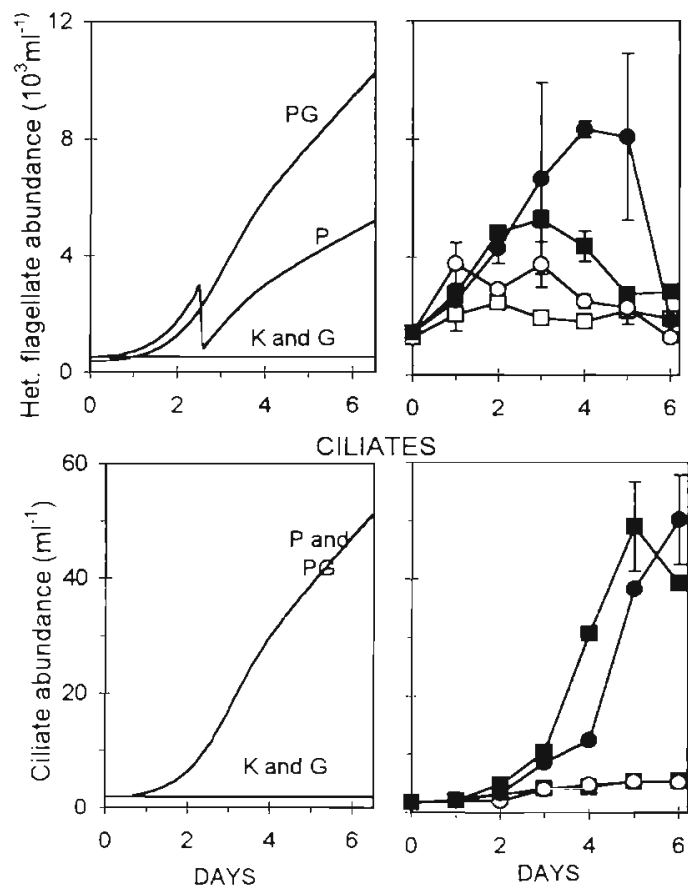

earlier and the subsequent decline larger than in the experiment. In microcosms with $\mathrm{P}$ additions ( $\mathrm{P}$ and $\mathrm{PG}$ ) autotrophic flagellates peaked on Day 4 and then declined (Fig. 4)

Disregarding the last day's decrease in PG microcosms, the model also reproduces the experimental observation of a difference in behavior of cyanobacteria and autotrophic flagellates with cyanobacteria increasing throughout the experiment in $\mathrm{P}$, and, except for the last day, also in PG microcosms.

The observed chlorophyll values remained low in microcosms without phosphate added ( $\mathrm{K}$ and $\mathrm{G}$ ) (approx. $0.25 \mu \mathrm{g} \mathrm{dm}^{-3}$ Days 4, 5, and 6), similar to autotrophic flagellates. In microcosms receiving $P$ without glucose (P microcosms), chlorophyll peaked on Day $4\left(2.3 \mu \mathrm{g} \mathrm{dm}^{-3}\right)$ then declined (approx. $1.5 \mu \mathrm{g}$ $\mathrm{dm}^{-3}$ J. In microcosms with both $\mathrm{P}$ and glucose additions (PG microcosms), chlorophyll peaked on Day 5 $\left(2.2 \mu \mathrm{g} \mathrm{dm}^{-3}\right)$ and then declined on Day $6\left(1.8 \mu \mathrm{g} \mathrm{l}^{-1}\right)$.
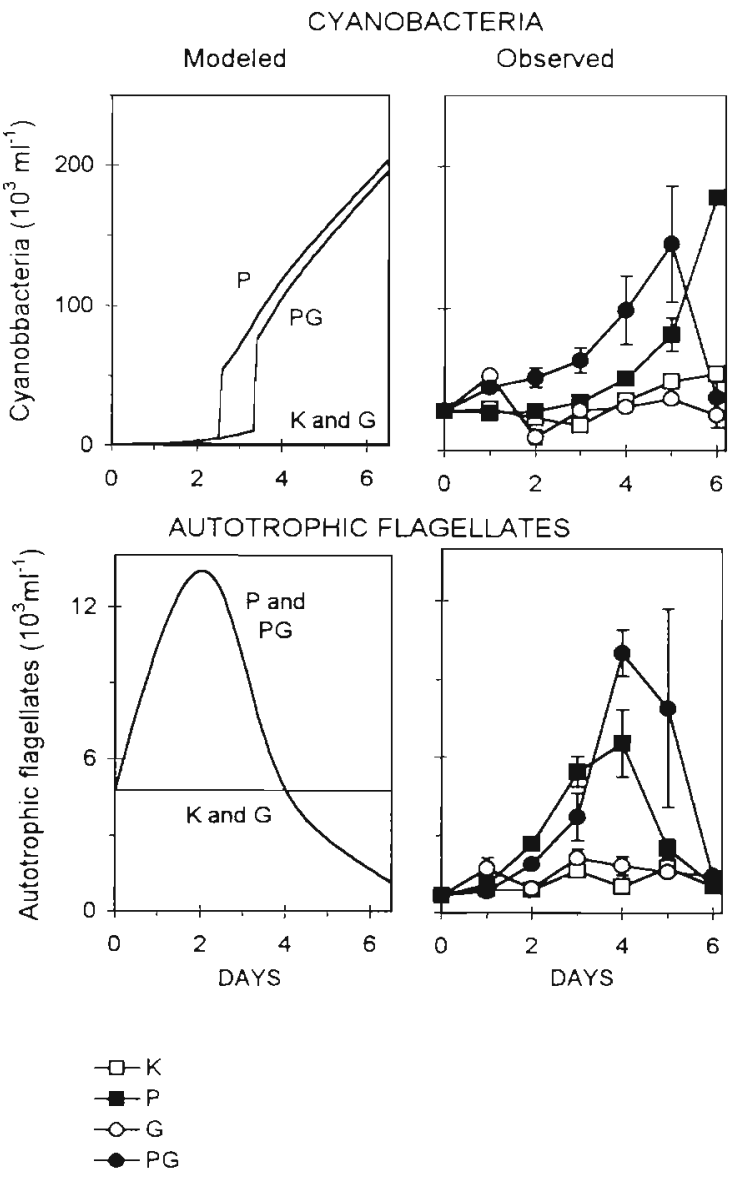

Fig. 4. Modeled and observed population changes over the course of the experiment

For the total experimental period, the P and PG microcosms received 6 additions, each of $50 \mathrm{nmol} \mathrm{P} \mathrm{dm}{ }^{-3}$. If all of this had been incorporated into phytoplankton biomass, it would correspond to an increase in chlorophyll of about $4.8 \mu \mathrm{g} \mathrm{chl} \mathrm{dm}^{-3}$ (assuming $\mathrm{C}: \mathrm{P}=$ $106 \mathrm{~mol}: \mathrm{mol}$ and $\mathrm{C}: \mathrm{chl}=80 \mathrm{w}: \mathrm{w})$, suggesting that transfer of added phosphorus into other compartments such as heterotrophic organisms was fairly efficient in our experiment.

However, neither in the case of heterotrophic bacteria, nor autotrophic flagellates, nor cyanobacteria can the model explain the differences in response observed in the P and PG microcosms (Fig. 4). Comparing the $\mathrm{P}$ and the $\mathrm{PG}$ microcosms, the model predicts only a shift in biomass from cyanobacteria to heterotrophic flagellates as a response to the glucose. The observations indicate a positive extra effect on bacterial abundance in the middle period of the experiment, perhaps indicating that glucose is a better substrate than some 
of the natural L-DOC left when the L-DOC pool is running out. Observations also indicate a difference in autotrophic flagellate abundance in P and PG microcosms, and, contrary to model predictions, there are more cyanobacteria in $\mathrm{PG}$ than in $\mathrm{P}$ microcosms (Fig. 4).

Heterotrophic flagellates were counted as 1 group. In $\mathrm{P}$ and $\mathrm{PG}$ microcosms these had a peak in abundance in the middle of the experiment. This is not reflected by our model where both pico- and nanosized heterotrophic flagellate abundance are proportional to ciliate abundance (Fig. 4). Presumably the heterotrophic flagellates share the same fate with the autotrophic flagellates, and are eaten by ciliates. The predator-prey relationship between ciliates and heterotrophic flagellates may thus be one point where our steady-state assumption gives an unsatisfactory description of the dynamics.

\section{DISCUSSION}

A simple intuitive expectation from adding phosphate to a P-deficient system would be a pattern of succession where the added P first induces a bloom phase in phytoplankton, and then, as a response to this increase in ciliate food supply, a subsequent phase where ciliate abundance increases and phytoplankton abundance decreases due to increased predation pressure. Our model reproduces this general pattern, but adds refinement in resolution by including a description for the manner whereby bacteria, different size classes of phytoplankion, and heterotrophic flagellates should respond. In the model, phosphate first enters the autotrophic flagellates (Eq. 12) and then, as the ciliate community responds, autotrophic flagellate abundance decreases (Eq. 12) while biomass and activity of the other populations in the BAFP system increase (Eqs. 7 to 11). Due to the P limitation of bacterial growth rate, glucose, when added alone, had no effect in the model other than an accumulation of DOC, and no shift to bacterial dominance is caused by such addition. Only after phosphate enrichment has shifted the balance between consumption and production of LDOC, and the pool of degradable DOC is depleted, is there a theoretical effect of glucose in shifting the distribution of phosphorus from cyanobacteria to heterotrophic picoflagellates. Although there are discrepancies between model and experiment, particularly in the effect of glucose on population changes following phosphate enrichment, the model reproduces sufficient general features of the changes observed in our experimental system to suggest the model contains essential features describing control of bacterial growth.
In this type of model, where higher predators exert a combined action on bacteria via mineral nutrient availability (bottom-up) and via predation (top-down), the steady state is characterized by a strong coupling between bacterial carbon demand $(B P)$ and the biomass in higher predators. The model used here with 2 phytoplankton competitors of the heterotrophic bacteria, and a 3-membered predator food chain, has the same type of $B P \propto C^{2}$ relationship for P-limited bacterial growth rate as the simpler food web structure analyzed by Thingstad et al. (1997). This may seem counter-intuitive since there is an extra step in the predator food chain from bacteria to ciliates. The effect is caused by $F_{1}$ being linked to the concentration of free phosphate via the steady state condition for $A_{1}$ (Eq. 2). Since free phosphate is linked to $C$ via the steady state condition for $A_{1}, F_{1}$ becomes proportional to $C$ (Eq. 9). $B P$ will thus be proportional both to $F_{1}$ and to $C$ although with different proportionality constants.

In the initial state, the model's production of L-DOC exceeds its consumption by heterotrophic bacteria, leading to a slow net accumulation of DOC in the model predictions for our control $(\mathrm{K})$ microcosms. With the production modeled as proportional to phytoplankton biomass, the model's consumption of L-DOC will increase faster than production as a response to phosphate enrichment. As long as parameters are chosen so that bacterial growth rate in the initial water is P-limited, a robust feature of the model is that the main shift in net balance between production and consumption of L-DOC will occur at the successional stage where autotrophic flagellate abundance culminates as a consequence of the rising ciliate population. As a consequence, growth rate of heterotrophic bacteria shifts from $\mathrm{P}$ to $\mathrm{C}$ limitation once the pool of accumulated LDOC has been consumed. Unfortunately, we have no direct measurements to prove that bacterial growth rate limitation changed at this stage of our experiments. In the model, the net effect of phosphate enrichment on the balance between L-DOC production and consumption would be even stronger if mineral nutrient limitation is assumed to stimulate phytoplankton LDOC excretion. If, alternatively, main L-DOC production instead was assumed to be linked to predation rates, production would increase with $C$. As a result, the shift to C-Iimited growth would be delayed. Our experimental results thus seem to suggest that the latter type of mechanisms were not the prime source of LDOC production in our experimental system. Thingstad et al. (1997) argued that, at extreme oligotrophy, bacterial growth rate must become C-limited. Our interpretation of the present experiments suggests that eutrophication, at least on the time-scale of these experiments, also may shift the system from $\mathrm{C}$ to $\mathrm{P}$ limitation of bacterial growth rate. 
In this model, the state with P-limited bacterial growth rate gives the maximum possible $B P$. The state with C-limited growth occurs only if the L-DOC supply is not large enough to meet this demand. With bacterial biomass not being affected, it means that, for a given value of $C$, bacteria grow slower under $C$ limitation than under $P$ limitation. In terms of their distance from maximum growth rate, bacteria thus experience $C$ limitation as a more adverse condition than P limitation.

The modeled difference in behavior patterns of cyanobacteria and autotrophic flagellates in microcosms receiving phosphate ( $\mathrm{P}$ and $\mathrm{PG}$ compared to $\mathrm{K}$ and $G$ microcosms), where cyanobacteria increased throughout, is also in accordance with observations, except for the last day in PG microcosms (Fig. 4). This suggests that the assumed structure of the predatory part of the food web, although suspected to be highly simplified, contains some of the essential features of the interactions occurring in the experimental microcosms.

If glucose was added alone (without phosphate), the model would predict an accumulation of L-DOC at a rate corresponding to that of glucose addition, and no effect on biomass or rates in the food web would be expected. Again, this effect is in qualitative accordance with observations (Fig. 3). Our data do not contain information as to whether accumulation occurred as glucose, whether the glucose was transformed to e.g. polysaccharides, or whether the glucose was preferentially used, leaving other substances to accumulate. Although the model seems to include essential elements required to describe the mechanisms regulating consumption of added L-DOC, the experiment does not necessarily prove the suggestion of Thingstad et al. (1997) that these mechanisms are crucial for accumulation of DOC in surface waters through the productive season (Copin-Montegut \& Avril 1993). Our experiment was too short, and also lacked the necessary measurements, to determine whether there is also an additional mechanism for production of recalcitrant DOC. There are in principle no difficulties in adding such a production to the model. Lacking the relevant experimental data, we have, however, chosen not to add such a mechanism here.

Parsons et al. (1981) described a mesocosm experiment where glucose added alone appeared to change the system toward heterotrophic dominance. This would be the effect in our model if bacterial growth rate in the initial, untreated system was C-, rather than mineral nutrient, limited. The generality of the assumed mineral nutrient limitation of bacterial growth rate in natural waters is not known. Theoretically, one can make an argument that $\mathrm{N}$ - and P-deficient systems may be different in this respect
(Thingstad et al. 1997). Taking the organic forms of $\mathrm{N}$ and $\mathrm{P}$ into consideration, bacteria may be expected to be superior to phytoplankton in sequestering organic forms of $N$ (e.g, amino acids), while this may be less pronounced for organic $\mathrm{P}$. If so, the probability for mineral nutrient limitation of bacterial growth rate would be less in $\mathrm{N}$ - than it is in P-deficient systems. Although phytoplankton are well known to possess extracellular alkaline phosphatases (e.g. Jansson et al. 1988), phytoplankton do also contain amino acid oxidases allowing them to sequester $\mathrm{N}$ from amino acids (Pantoja \& Lee 1994). Without further experimental evidence, the question of differences in $\mathrm{C}$ limitation of bacteria between $\mathrm{N}$ - and $\mathrm{P}$-deficient systems remains open.

The theoretical aspects of the model used here have not been explored extensively. Note, however, the non-intuitive effect of phytoplankton-bacteria competition on bacterial production. The effect of phytoplankton physiology on bacterial production is given by the composite proportionality factor $\alpha_{A_{1}} / \alpha_{A_{2}}{ }^{2}$ (Eq. 13). As a consequence, an efficient nutrient uptake in autotrophic flagellates will have a strong negative effect on bacterial production, while, more surprisingly, efficient nutrient uptake in cyanobacteria according to this model will stimulate $B P$. The reason is that, with the assumed food web structure, increased cyanobacterial affinity leads to more heterotrophic nanoflagellates (Eq. 9). This gives a higher loss rate of heterotrophic picoflagellates. To compensate for this loss, there must be a higher growth rate, i.e. a higher food concentration, i.e. a higher bacterial biomass at equilibrium. Hence a positive effect of $\alpha_{A_{1}}$ on bacterial production. Our data set does not contain sufficient information to test this aspect of the model.

Note that our experimental system was not designed to add proof to the suggested $\mathrm{P}$, rather than $\mathrm{N}$, deficiency of the Mediterranean (Krom et al. 1991). Our experimental system was forced to a situation with free nitrate to avoid ambiguity as to whether $\mathrm{P}$ or $\mathrm{N}$ was the most limiting mineral nutrient.

The model used here can easily be reformulated to use a full description in differential equations, also for the components inside the BAFP system. Doing this (differential equations solved using the ${ }^{\circledR}$ Stella II software), a better fit to observation could be achieved for some aspects such as a more rapid response in $B P$, and a later culmination in autotrophic flagellates. However, due to a tendency towards large fluctuations in the modeled populations (results not shown), not in accordance with observations, benefits from using the full differential-equation description of this simple model were not obvious. The correspondence between fully dynamic descriptions and hybrid dynamic-steady state models as used here therefore needs further exploration. Advantages of the proposed approach lie not 
only in the increased analytical power when explicit solutions are available (Appendices 2 \& 3), but also in vastly increased computational speed. With this method, the state of the system of fast organisms is solved algebraically, and time steps for numerical integration can be adjusted to the dynamics of slower growing organisms. This may be of great potential value should microbial processes be added to dynamic ocean models.

Although discrepancies between model and observations were found, we are not aware of alternative models able to explain the combined observation of no response, except DOC accumulation, to glucose when added alone, while glucose at the same time enhances the stimulation in $B P$ resulting from phosphate enrichment. We thus suggest that our model contains the basic elements of the system of trophic interactions regulating $\mathrm{P}$ competition and $\mathrm{L}-\mathrm{DOC}$ consumption in our experimental system. Due to the relative simplicity of the model, its amenability to analytical solution, and the relative ease by which it allows dynamic behavior to be inferred from population properties, we also conclude that the modeling approach used here provides a useful tool in the otherwise fairly difficult task of elucidating the mechanisms behind the dynamic behavior observed in such experimental systems.

Appendix 1. Steady state description of the BAFP system. See Table 1 for definitions

Steady state of heterotrophic bacteria requires:

$\alpha_{B} P B=\alpha_{F_{10}} B F_{0}$ for P-limited growth rate, or

$\frac{Y_{B C} \psi}{r_{B}}=\alpha_{F_{n}} B F_{0}$ for C-limited bacterial growth rate (1b)

(growth = predation)

For cyanobacteria

$$
\alpha_{A_{1}} p_{A_{1}}=\alpha_{F_{1}} A_{1} F_{1}
$$

for autotrophic flagellates:

$$
\alpha_{A_{2}} p_{A_{2}}=\alpha_{C} A_{2} C
$$

for heterotrophic picoflagellates:

$$
Y_{F_{0}} \alpha_{F_{1}} B F_{6}=\alpha_{F_{1}} F_{0} F_{1}
$$

and for heterotrophic nanoflagellates:

$$
Y_{F_{1}} \alpha_{F_{1}}\left(A_{1}+F_{0}\right) F_{1}=\beta_{C} \alpha_{C} F_{1} C
$$

where $\beta_{C}$ is a dimensionless selectivity factor for ciliate rolative preference for heterotrophic nanoflagellates versus autotrophic flagellates.

Finally, mass balance for mineral nutrients requires:

$$
P_{\mathrm{t}}=P+B+A_{1}+A_{2}+F_{0}+F_{!}
$$

Acknowledgements. This work has been financed by the EU MASTIII program, contract MAS3-CT95-0016 'MEDEA', the support program between ELF Petroleum, Norway, and the University of Bergen, and a Eusko Jaurlaritza (Basque government) grant to M.P.

\section{LITERATURE CITED}

Bjørnsen PK (1988) Phytoplankton exudation of organic matter: why do healthy cells do it? Limnol Oceanogr 33: $151-154$

Bratbak G, Thingstad TF (1985) Phytoplankton-bacteria interactions: an apparent paradox? Analysis of a model system with both competition and commensalism. Mar Ecol Prog Ser 25:23-30

Copin-Montegut G, Avril B (1993) Vertical distribution and temporal variation of dissolved organic carbon in the North-Western Mediterranean Sea. Deep-Sea Res 40: 1963-1972

Appendix 2. Solution to the set of equations from Appendix 1 when bacterial growth rate is P-limited (and all variables $B$, $A_{1}, A_{2}, F_{0}$, and $F_{1}>0$ ). See Table 1 for definitions

Solving Eq. (3) for $P$ gives:

$$
P=\frac{\alpha_{C}}{\alpha_{A_{2}}} C
$$

With $P$ thus determined by the requirement that growth must equal loss of autotrophic flagellates, $F_{0}$ and $F_{1}$ can be determined from the requirements that growth must equal loss for heterotrophic bacteria (Eq. 1a) and autotrophic flagellates (Eq. 3), respectively:

$$
\begin{aligned}
& F_{0}=\frac{\alpha_{B}}{\alpha_{F_{0}}} \frac{\alpha_{C}}{\alpha_{A_{2}}} C \\
& F_{1}=\frac{\alpha_{A_{1}}}{\alpha_{F_{1}}} \frac{\alpha_{C}}{\alpha_{A_{2}}} C
\end{aligned}
$$

With $F_{1}$ determined (Eq. 9), $B$ can be determined from the steady state condition of heterotrophic picoflagellates (Eq. 4):

$$
B=\frac{\alpha_{A_{1}} \alpha_{C}}{Y_{F_{0}} \alpha_{F_{0}} \alpha_{A_{2}}} C
$$

With $F_{0}$ determined (Eq. 8), $A_{1}$ can be determined from the steady state requirement of heterotrophic nanoflagellates (Eq. 5):

$$
A_{1}=\left(\frac{\beta}{Y_{F_{1}}}-\frac{\alpha_{A_{1}}}{\alpha_{A_{2}}}\right) \frac{\alpha_{C}}{\alpha_{F_{1}}} C
$$

Finally, from the mass balance reçuirement (Eq. 6), $A_{2}$ can be determined as:

$$
A_{2}=P_{1}-\left(\frac{1}{\alpha_{A_{2}}}+\frac{\alpha_{B}}{\alpha_{F_{1}} \alpha_{A_{2}}}+\frac{1}{Y_{F_{0}} \alpha_{F_{11}}} \frac{\alpha_{A_{1}}}{\alpha_{A_{2}}}+\frac{\beta}{Y_{F_{1}} \alpha_{F_{1}}}\right) \alpha_{C} C
$$

Bacterial production $(B P$ ) can then be derived by insertion of the steady state expressions for $P$ and $B$ :

$$
B P=\alpha_{B_{3}} P B=\frac{\alpha_{B} \alpha_{A_{i}}}{Y_{F_{1}} \alpha_{F_{0}} \alpha_{A_{2}}^{2}} \alpha_{C}^{2} C^{2}
$$


Cotner JB, Ammerman JW, Peele ER, Bentzen E (1997) Phosphorus-limited bacterioplankton growth in the Sargasso Sea. Aquat Microb Ecol 13:141-149

Dixon M, Webb EC (1964) Enzymes. Academic Press Inc New York

Fuhrman J, Azam F (1980) Bacterioplankton secondary production estimates for coastal waters of British Columbia, Antarctica, and California. Appl Environ Microbiol 39: $1085-1095$

Fuhrman JA, Azam F (1982) Thymidine incorporation as a measure of heterotrophic bacterioplankton production in marine surface waters: evaluation and field results. Mar Biol 66:109-120

Hagström $\AA$, Larsson U, Hörstedt P. Normark S (1979) Frequency of dividing cells, a new approach to the determination of bacterial growth rates in aquatic environments. Appl Environ Microbiol 37:805-812

Jansson M, Olsson H, Petterson K (1988) Phosphatases: ori-

Appendix 3. Solution for the steady state with C-limited bacterial growth rate. See Table 1 for definitions

Following the arguments in Appendix 2, one will see that the expressions for $P, B$, and $F_{1}$ will be unaltered by exchanging $P$ limitation of bacterial growth rate with $C$ limitation. Also, the sum $A_{1}+F_{0}$ will remain unaltered:

$$
A_{1}+F_{0}=\frac{1}{Y_{F_{1}} \alpha_{F_{1}}} \beta \alpha_{C} C
$$

This also means that $A_{2}$, given by:

$$
A_{2}=P_{\mathrm{t}}-P-B-F_{1}-\left(A_{1}+F_{0}\right)
$$

will remain unaltered

The difference in biomass distribution when bacterial growth rate is $\mathrm{C}$-limited is thus restricted to a shift in biomass from heterotrophic picoflagellates to cyanobacteria. $F_{0}$ is determined by the supply rate $\psi$ of L-DOC. From Eq. (1b):

$$
F_{0}=\frac{1}{\alpha_{F_{0}}} \frac{Y_{B C} \psi}{r_{B} B}
$$

which, from Eq. (14), gives $A_{1}$ as:

$$
A_{1}=\frac{1}{Y_{F_{1}} \alpha_{F_{1}}} \beta \alpha_{C} C-\frac{1}{\alpha_{F_{0}}} \frac{Y_{B C} \psi}{r_{B} B}
$$

The type of mechanism chosen for L-DOC production $\psi$ will thus determine the balance between cyanobacteria $\left(A_{1}\right)$ and heterotrophic picoflagellates $\left(F_{0}\right)$. In reality, the autochthonous part of $\psi$ is probably a fairly complex function of the state variables. Here we have only explored the simple model where there is a release of L-DOC proportional to phytoplankton biomass:

$$
\psi=k x_{P}\left(A_{1}+A_{2}\right)+\psi_{E}
$$

where $\psi_{E}$ is the allochthonous input rate of L-DOC (glucose)

Insertion of Eq. (18) into Eq. (17) and solving for $A_{1}$ gives:

$$
A_{1}=\frac{\frac{Y_{B C}}{\alpha_{F_{0}} r_{B} B}}{1+\frac{Y_{B C} k}{\alpha_{F_{4}} r_{B} B}}\left(\frac{\beta \alpha_{F_{0}} r_{B} B}{Y_{B C} Y_{F_{1}} \alpha_{F_{1}}} \alpha_{C} C-k A_{2}-\psi_{E}\right)
$$

gin, characteristics and function in lakes. Hydrobiologia 170:157-175

Krom MD, Kress N, Brenner S, Gordon LI (1991) Phosphorus limitation of primary productivity in the eastern Mediterranean Sea. Limnol Oceanogr 36:424-432

Landry MR (1983) The development of marine calanoid copepods with comment on the isochronal rule. Limnol Oceanogr 28:614-624

Pantoja S, Lee C (1994) Cell-surface oxidation of amino acids in seawater. Limnol Oceanogr 39:1718-1725

Parsons TR, Albright LJ, Whitney F, Wong CS, Williams PJleB (1981) The effect of glucose on the productivity of seawater: an experimental approach using controlled aquatic ecosystems. Mar Environ Res 4:229-242

Pomeroy LR, Sheldon JE, Sheldon WMJ, Peters F (1995) Limits to growth and respiration of bacterioplankton in the Gulf of Mexico. Mar Ecol Prog Ser 117:259-268

Porter KG, Feig YS (1980) The use of DAPI for identifying and counting aquatic microflora. Limnol Oceanogr 25:943-948

Putt M. Stoecker DK (1989) An experimentally determined carbon:volume ratio for marine oligotrichous ciliates from estuarine and coastal waters. Limnol Oceanogr 34: $1713-1731$

Smith D, Azam F (1992) A simple, economical method for measuring bacterial protein synthesis in seawater using ${ }^{3} \mathrm{H}$-leucine. Mar Microb Food Webs 6:107--114

Sugimura Y, Suzuki Y (1988) A high-temperature catalytic oxidation method for the determination of non-volatile dissolved organic carbon in seawater by direct injection of a liquid sample. Mar Chem 24:105-131

Thingstad TF, Lignell R (1997) A theoretical approach to the question of how trophic interactions control carbon demand, growth rate, abundance, and diversity. Aquat Microb Ecol 113:19-27

Thingstad TF, Skjoldal EF, Bohne RA (1993) Phosphorus cycling and algal-bacterial competition in Sandsfjord, western Norway. Mar Ecol Prog Ser 99:239-259

Appendix 4. Differential equations describing the temporal changes in mesozooplankton and in total microbial nutrient $P_{t}$. See Table 1 for definitions

Ciliates C:

$$
\begin{array}{r}
\frac{\mathrm{d} C}{\mathrm{~d} t}=Y_{C} \alpha_{C}\left(A_{2}+\beta_{C} F_{1}\right) C-\delta_{C} C \\
\text { (growth }- \text { death) }
\end{array}
$$

Nutrient content $P_{1}$ of the microbial complex:

$$
\frac{\mathrm{d} P_{1}}{\mathrm{~d} t}=q_{E}-Y_{C} \alpha_{C}\left(A_{2}+\beta_{C} F_{1}\right) C+\delta_{C} C
$$

(allochthonous nutrient addition - predatory loss + phosphorus recycled from ciliate death)

$$
\frac{\mathrm{d} \mathrm{L}-\mathrm{DOC}}{\mathrm{d} t}=\psi_{E}+k r_{P}\left(A_{1}+A_{2}\right)-Y_{B C}^{-1} \alpha_{B} P B
$$

if L-DOC $>0$ (P-limited bacteria)

$$
\frac{\mathrm{d} \mathrm{L}-\mathrm{DOC}}{\mathrm{d} t}=0
$$

if $\mathrm{L}$-DOC $=0$ (C-limited bacteria)

The differential equations were solved by a simple Euler algorithm using a $2 \mathrm{~h}$ time step 
Thingstad TF, Hagström $\AA$, Rassoulzadegan F (1997) Export of degradable DOC from oligotrophic surface waters: caused by a malfunctioning microbial loop? Limnol Oceanogr 42:398-404

Thingstad TF, Zweifel UL, Rassoulzadegan F (1998) P-limitation of both phytoplankton and heterotrophic bacteria in NW Mediterranean summer surface waters. Limnol Oceanogr 43:88-94

Thingstad TF, Havskum $H$, Kaas $H$, Lefevre D, Nielsen $T G$, Riemann B Williams PJleB (1999) Bacteria-protist interactions and organic matter degradation under $\mathrm{P}$-limited conditions: analysis of an enclosure experiment using a simple model. Limnol Oceanogr 44:62-79

Editorial responsibility: Tom Fenchel,

Helsinger, Denmark
Tréguer P, Le Corre P (1975) Manuel d'analyse des sels nutritifs dans l'eau de mer (utilisation de l'AutoAnalyser II Technicon), 2nd edn. Université de Bretagne Occidentale, Brest

Williams PJleB (1990) The importance of losses during microbial growth: commentary on the physiology, measurement, and ecology of the release of dissolved organic material. Mar Microb Food Webs 4:175-206

Zohary T, Robarts RD (1998) Experimental study of microbial $P$ limitation in the eastern Mediterranean. Limnol Oceanogr 43:387-395

Zweifel UL, Norrman B, Hagström $\AA$ (1993) Consumption of dissolved organic carbon by marine bacteria and demand for inorganic nutrients. Mar Ecol Prog Ser 101:23-32

Submitted: June 15, 1998; Accepted: January 4, 1999 Proofs received from author(s): July 23, 1999 